\section{Список литературы}

1. Лукьянова Л.Д. Молекулярные механизмы тканевой гипоксии и адаптация организма / Л.Д. Лукьянова // Физиологический журнал. 2003. - Т.49. - №3. - С. 17-35.

2. Лукьянова Л.Д. Роль биоэнергетических нарушений в патогенезе гипоксии // Патол.физиол. и эксперим. терапия. М., 2004. - №2. - С. 2-11.

3. Царегородцев А. Д. Коррекция метаболических состояний при различных патологических состояниях у детей. - М.: 2006. -87 c.

4. Лукьянчук В. Д. Антигипоксанты: состояние и перспективы / В. Д. Лукьянчук, Л. В.Савченкова // Экспериментальная и клиническая фармакология. - 1998. - Т. 61. №4. - С. 72-79.

5. Международные рекомендации по проведению медико-биологических исследований с использованием животных. / Ланималогия. - 1993. - №1. - С.29-31.

6. Шараев П. Н. Метод определения свободного и связанного оксипролина в сыворотке крови / П. Шараев. // Лаб. дело. - 1981. - № 5. - С. 283-285.

7. Метод определения гликазаминогликанов в биологических жидкостях. / [П. Шараев, В. Пешков, Н. Соловьева, Т. Широкова, Н. Зворыгина, А. Солопаев, Н. Алексеева] // Лабораторное дело. - 1987. - 5. - С. 330-332.

8. Стальная И. Д. Метод определения диеновых конъюгаций ненасыщенных высших жирных кислот / И. Стальная, Т. Гаришвили // Современные методы биохимии / Под ред. В.Н. Ореховича. - М. - 1977. - С.63-64.

9. А.С.922637 СССР. МКИ 01 33/48. Способ определения активности глутатион-пероксидазы в биологических тканях / В. Пахомова, Н. Козлянина, Г. Крюкова. - Опубл. 25.04.82, Бюл. №15. - 2 с.

10. Королюк М. А. Метод определения активности каталазы / М. Королюк., Д. Иванова, И. Майорова // Лабораторное дело. - 1988. - №1. - С. 16-18.

11. Николаева А.В. Влияние некоторых нейротропных средств на состояние тканей при раздражении верхнего шейного симпатического узла: автореф. дис. на соискание учен. степени канд. мед. наук / А. Николаева - Харьков. 1967. $-29 \mathrm{c}$.

\section{REFERENCES}

1. Lukyanova L.D. Molecular mechanisms of tissue hypoxia and body adaptation. Fiziologicheskij zhurnal, 2003: 49(3):17-35.

2. Lukyanova L.D. The role of bioenergetic disorders in the pathogenesis of hypoxia. Patol.fiziolog. $i$ eksperim. terapiya, 2004:2: 2-11.

3. Caregorodcev A.D. Korrekciya metabolicheskih sostoyanij pri razlichnyh patologicheskih sostoyaniyah $u$ detej [Correction of metabolic conditions in various pathological conditions in children] M, 2006:87.

4. Lukyanchuk V. D. Antihypoxants: status and prospects. Eksperimentalnaya I klinicheskaya farmakologiya, 1998:61(4):72-79.

5. International recommendations for biomedical research using animals. Lanimalogiya, 1993: 1: 29-31.

6. Sharaev P. N. Method for determination of free and bound hydroxyproline in blood serum. Lab. delo, 1981: 5: 283285.

7. Sharaev P. N., Peshkov V. Method for the determination of glycazaminoglycans in biological fluids. Lab. delo, 1987: 5: $330-332$.

8. Stalnaya I. D., Garishvili T. G. Metod opredeleniya malonovogo dialdegida s pomoshchyu tiobarbiturovoy kisloty [The method of revelation of malonic dialdehyde with thiobarbituric acid]. Moskva, Meditsina, 1977: 66-68.

9. Pakhomova V., Kozlyanina N., Kryukova G. A.S. 922637 of the USSR. MKI 01 33/48. Sposob opredeleniya aktivnosti glutation-peroksidazy $v$ biologicheskih tkanyah [A method for determining the activity of glutathione peroxidase in biological tissues] Publ. 04/25/82, Bull.15:2 p.

10. Korolyuk M. A. Method for determining the activity of catalase. Lab.delo, 1988: 1: 16-18.

11. Nikolaeva A.V. Vliyanie nekotoryh nejrotropnyh sredstv na sostoyanie tkanej pri razdrazhenii verhnego shejnogo simpaticheskogo uzla [The effect of some neurotropic drugs on the state of tissues with irritation of the upper cervical sympathetic ganglion]: Author. dis. PhD, Kharkov, 1967:29.

Поступила 17.04.20

УДК 57.084.1:[616.31+599.323.45]

DOI https://doi.org/10.35220/2523-420X/2020.1.4

*С.В. Скульская, к. мед. н., О.А. Макаренко, д. биол.н., О.В. Деньга, д. мед. н.

Национальная медицинская академия последипломного образования имени П. Л. Шупика Государственное учреждение «Институт стоматологии и челюстно-лицевой хирургии Национальной академии медицинских наук Украины»

\title{
КОРРЕКЦИЯ БИОХИМИЧЕСКИХ ПОКАЗАТЕЛЕЙ В СЫВОРОТКЕ КРОВИ И ТКАНЯХ ПОЛОСТИ РТА КРЫС ПРИ ЭКСПЕРИМЕНТАЛЬНОМ МОДЕЛИРОВАНИИ АНТРОПОГЕННОГО ЗАГРЯЗНЕНИЯ
}

Актуальность. Антропогенное загрязнение окружающуей среды оказывает увеличение стоматологической заболеваемости. При этом установлена высокая распространенность кариеса и некариозных поражений твердых тканей зубов, заболеваний пародонта и слизистой оболочки полости рта у детского населения. 
Целью данного исследования была экспериментальная оценка изменений биохимических показателей сыворотки крови и тканей полости рта крыс под действием лечебно-профилактических мероприятий, разработанных для детей, проживающих в зоне антропогенного загрязнения нефтехимическим производством.

Материалы и методы. В сыворотке крови, гомогенатах кости альвеолярного отростка, слизистой оболочки полости рта и печени крыс определяли содержание малонового диальдегида, активность каталазы, активность глутатионпероксидазы и глутатион-редуктазы и уровень дисульфидных и сульфгидрильных водорастворимых соединений.

Выводы. Проведение лечебно-профилактических мероприятий оказало выраженный лечебнопрофилактический эффект - стимулящию антиоксидантной защиты в организме и тканях полости pma.

Ключевые слова: биохимия, антропогенная нагрузка, крысы, ротовая полость.

\section{"С.В. Скульська, О.А. Макаренко, О.В. Дєньга}

*Національний медична академія післядипломної освіти імені П. Л. Шупика Державна установа «Інститут стоматології та щелепно-лицевої хірургії

Національної академії медичних наук України»

\section{КОРЕКЦІЯ БІОХІМІЧНИХ ПОКАЗНИКІВ У СИРОВАТЦІ КРОВІ І ТКАНИНАХ ПОРОЖНИНИ РОТА ЩУРІВ ПРИ ЕКСПЕРИМЕНТАЛЬНОМУ МОДЕЛЮВАННІ АНТРОПОГЕННОГО ЗАБРУДНЕННЯ}

Актуальність. Антропогенне забруднення навколишнього середовища надає збільшення стоматологічної захворюваності. При иьому встановлена висока поширеність карієсу і некаріозних уражень твердих тканин зубів, захворювань пародонту і слизової оболонки порожнини рота у дитячого населення.

Метою даного дослідження була експериментальна оцінка змін біохімічних показників сироватки крові та тканин порожнини рота щурів під дією лікувально-профілактичних заходів, розроблених для дітей, які проживають в зоні антропогенного забруднення нафтохімічних виробництвом.

Матеріали та методи. У сироватиі крові, гомогенатах кістки альвеолярного відростка, слизової оболонки порожнини рота і печінки щурів визначали вміст малонового діальдегіду, активність каталази, активність глутатіонпероксидази і глутатіон-редуктази і рівень дисульфідних і сульфгідрильних водорозчинних сполук.

Висновки. Проведення лікувально-профілактичних заходів зробило виражений лікувальнопрофілактичний ефект - стимуляцію антиоксидантної захисту в організмі і тканинах порожнини poma.

Ключові слова: біохімія, антропогенне навантаження, щури, ротова порожнина.

\section{Skulskaya S.V., Makarenko O.A., Denga O.V. \\ *National Medical Academy of Postgraduate Education named after P.L. Shupyk \\ ${ }^{2}$ State Establishment "The Institute of Stomatology and Maxillofacial Surgery of the National Academy of Medical Sciences of Ukraine" \\ CORRECTION OF BIOCHEMICAL INDICES IN SERUM OF BLOOD AND TISSUES OF THE ORAL CAVITY OF RATS IN EXPERIMENTAL MODELING OF ANTHROPOGENIC POLLUTION}

\section{ABSTRACT}

Relevance. Anthropogenic pollution has an increase in dental disease. At the same time, a high prevalence of caries and non-carious lesions of hard tooth tissues, periodontal diseases and oral mucosa in children was established.

The aim of this study was an experimental assessment of changes in the biochemical parameters of blood serum and tissues of the oral cavity of rats under the influence of therapeutic and preventive measures designed for children living in the zone of anthropogenic pollution by petrochemical production.

Materials and methods. The content of malondialdehyde, the activity of catalase, the activity of glutathione peroxidase and glutathione reductase and the level of disulfide and sulfhydryl water-soluble com- 
pounds were determined in blood serum, homogenates of the bone of the alveolar ridge, oral mucosa and rat liver.

Findings. The treatment and preventive measures had a pronounced therapeutic and prophylactic effect - stimulation of antioxidant protection in the body and tissues of the oral cavity.

Keywords: biochemistry, anthropogenic load, rats, oral cavity.

Антропогенное загрязнение окружающей среды оказывает увеличение стоматологической заболеваемости. При этом установлена высокая распространенность кариеса, некариозных поражений твердых тканей зубов, заболеваний пародонта и слизистой оболочки полости рта у детского населения [1-3]. Вместе с тем, учитывая то, что уровни антропогенной нагрузки определяются региональным компонентом, необходимо констатировать, что до настоящего времени в городе Белая Церковь не проводилась оценка влияния антропогенного загрязнения на уровень распространенности и структуру стоматологической заболеваемости, а также оценка эффективности патогенетически обоснованных лечебнопрофилактических мероприятий детского населения.

Цель данного исследования. Экспериментальная оценка изменений биохимических показателей сыворотки крови и тканей полости рта крыс под действием лечебно-профилактических мероприятий, разработанных для детей, проживающих в зоне антропогенного загрязнения нефтехимическим производством.

Материалы и методы. В эксперименте использовали 27 одномесячных крыс линии Вистар стадного разведения. Сочетанную кальцийдефицитную модель кариеса и гингивита моделировали у 18 крыс в течении 60 дней при помощи перорального введения раствора пелентана (Лахия, Чехия) в дозе 10 мг/кг через день в утренние часы. На протяжении всего эксперимента животные также получали с питьевой водой $2 \%$ ный раствор этилендиаминтетрауксусной кислоты (ЭДТА) ad libitum [1]. Интактную группу составили 9 крыс такого же возраста.

Лечебно-профилактический комплекс (ЛПК) крысам ежедневно вводили per os утром через неделю после начала эксперимента, который включал препараты: «Энтеросгель» - 2,7 г/кг (сорбционное, дезинтоксикационное действие), «Гринтерол» - 70 мг/кг (гепатопротекторное, гипогликемическое, иммуномодулирующее действие), «Пантокрин» - 2 капли/кг (оказывает стимулирующее действие на ЦНС и сердечнососудистую систему, повышает тонус скелетных мышц, двигательную активность кишечника), «Аквадетрим» - $90 \mathrm{ME/кг} \mathrm{(восполняющее} \mathrm{дефи-}$ цит макро- и микроэлементов, восполняющее дефицит витаминов, нормализующее обменные процессы действие). Вечером отдельно от препаратов вводили препарат «Зостерин-ультра» - 100 мг/кг (энтеросорбент, гемосорбент и иммуномодулятор).

Профилактику препаратами начинали с 1ого дня моделирования кариеса и гингивита. Крысы были разделены на группы по 9 в каждой: 1 - рацион вивария; 2 - модель кариеса и гингивита (МКГ); 3 - МКГ + профилактика.

Через 60 дней у крыс собирали слюну при пилокарпиновой стимуляции (3 мг/кг) под гиопенталовым наркозом (20 мг/кг). Затем животных выводили из эксперимента путем кровопускания из сердца, выделяли блоки челюстей с зубами, слизистую оболочку полости рта (СОПР), печень, собирали сыворотку крови. В сыворотке крови, гомогенатах кости альвеолярного отростка, СОПР и печени определяли содержание малонового диальдегида (МДА) [4], активность каталазы [5], активность глутатионпероксидазы (ГПО) [6] и глутатион-редуктазы (ГР) [7] и уровень дисульфидных и сульфгидрильных водорастворимых соединений [8].

Результаты и обсуждение. Моделирование кальций-дефицитной модели кариеса и гингивита привело к существенным нарушениям в системе антиоксидантная система (АОС) - перекисное окисление липидов (ПОЛ) организма животных. Об этом заключили по результатам исследования содержания МДА и активности каталазы в сыворотке крови, печени, СОПР и тканях альвеолярной кости крыс (табл. 1).

Через 60 дней после моделирования патологии, вызываемой антропогенным загрязнением, зарегистрирована активация процессов ПОЛ, о чём заключили по достоверному увеличению содержания МДА во всех исследуемых тканях. Длительный алиментарный дефицит кальция вызвал увеличение МДА в сыворотке крови в 2,9 раза, в печени - в 1,8 раза, СОПР - в 1,6 раза, в альвеолярной кости - в 1,8 раза (табл.1). Воспалительные процессы в СОПР зарегистрированы по накоплению одного из маркеров воспаления МДА.

На фоне моделирования патологии введение комплекса профилактических препаратов эффективно предотвращало интенсификацию ПОЛ в организме крыс. Как видно из данных таблицы 1 в сыворотке крови крыс 3-ей группы содержание МДА достоверно ниже, чем в сыворотке крыс 2- 
ой группы $\left(\mathrm{p}_{1}<0,005\right)$, хотя и выше, чем у интактных животных $(\mathrm{p}<0,1)$. В печени, СОПР и тканях альвеолярного отростка крыс, получав- ших профилактические препараты, уровень МДА не превышал нормальных значений ( $>>0,1$; табл. $1)$.

Таблица 1

\section{Влияние лечебно-профилактического комплекса на содержание малонового диальдегида, ак- тивности каталазы и антиоксидантно-прооксидантного индекса у крыс на фоне кальций- дефицитной модели, $\mathrm{M} \pm \mathbf{m}$}

\begin{tabular}{|c|c|c|c|}
\hline Ткани & $\begin{array}{c}\text { Интактная } \\
\text { группа }\end{array}$ & Модель кариеса и гингивита & МКГ + комплекс \\
\hline \multicolumn{4}{|c|}{ Содержание МДА } \\
\hline Сыворотка крови, ммоль/кг & $0,81 \pm 0,10$ & $\begin{array}{l}2,34 \pm 0,36 \\
\mathrm{p}<0,001\end{array}$ & $\begin{array}{c}1,17 \pm 0,19 \\
\mathrm{p}>0,1 \\
\mathrm{p}_{1}<0,005\end{array}$ \\
\hline Печень, ммоль/кг & $38,2 \pm 4,17$ & $\begin{array}{l}67,4 \pm 7,35 \\
p>0,005\end{array}$ & $\begin{array}{c}43,1 \pm 3,86 \\
p>0,1 \\
p_{1}<0,005\end{array}$ \\
\hline СОПР, ммоль/кг & $18,3 \pm 2,5$ & $\begin{array}{l}29,4 \pm 3,1 \\
p<0,005\end{array}$ & $\begin{array}{c}20,3 \pm 2,4 \\
\mathrm{p}>0,1 \\
\mathrm{p}_{1}<0,01\end{array}$ \\
\hline $\begin{array}{c}\text { Альвеолярная кость, } \\
\text { ммоль/кг }\end{array}$ & $43,4 \pm 5,1$ & $\begin{array}{l}76,2 \pm 4,8 \\
p<0,001\end{array}$ & $\begin{array}{c}51,4 \pm 6,3 \\
\mathrm{p}>0,1 \\
\mathrm{p}_{1}<0,005\end{array}$ \\
\hline \multicolumn{4}{|c|}{ Активность каталазы } \\
\hline Сыворотка крови, ммоль/кг & $0,32 \pm 0,05$ & $\begin{array}{l}0,18 \pm 0,02 \\
\mathrm{p}<0,05\end{array}$ & $\begin{array}{c}0,25 \pm 0,03 \\
\mathrm{p}>0,1 \\
\mathrm{p}_{1}<0,1\end{array}$ \\
\hline Печень, ммоль/кг & $6,5 \pm 0,7$ & $\begin{array}{l}4,4 \pm 0,5 \\
p<0,05\end{array}$ & $\begin{array}{c}5,1 \pm 0,7 \\
\mathrm{p}>0,1 \\
\mathrm{p}_{1}>0,1\end{array}$ \\
\hline СОПР, ммоль/кг & $9,3 \pm 0,8$ & $\begin{array}{l}6,4 \pm 0,9 \\
p<0,05\end{array}$ & $\begin{array}{l}7,8 \pm 0,9 \\
\mathrm{p}>0,1 \\
\mathrm{p}_{1}>0,1\end{array}$ \\
\hline $\begin{array}{c}\text { Альвеолярная кость, } \\
\text { ммоль/кг }\end{array}$ & $3,81 \pm 0,10$ & $\begin{array}{l}3,05 \pm 0,08 \\
\mathrm{p}<0,001\end{array}$ & $\begin{array}{c}4,26 \pm 0,4 \\
\mathrm{p}>0,1 \\
\mathrm{p}_{1}<0,005\end{array}$ \\
\hline \multicolumn{4}{|c|}{ Антиоксидантно-прооксидантный индекс } \\
\hline Сыворотка крови, ммоль/кг & $3,95 \pm 0,47$ & $\begin{array}{l}0,77 \pm 0,06 \\
\mathrm{p}<0,001\end{array}$ & $\begin{array}{c}2,14 \pm 0,31 \\
\mathrm{p}>0,05 \\
\mathrm{p}_{1}<0,001\end{array}$ \\
\hline Печень, ммоль/кг & $1,70 \pm 0,24$ & $\begin{array}{l}0,65 \pm 0,09 \\
\mathrm{p}<0,001\end{array}$ & $\begin{array}{c}1,18 \pm 0,16 \\
\mathrm{p}<0,1 \\
\mathrm{p}_{1}<0,009\end{array}$ \\
\hline СОПР, ммоль/кг & $5,08 \pm 0,49$ & $\begin{array}{l}2,18 \pm 0,31 \\
\mathrm{p}<0,001\end{array}$ & $\begin{array}{c}3,84 \pm 0,27 \\
\mathrm{p}>0,05 \\
\mathrm{p}_{1}<0,001\end{array}$ \\
\hline $\begin{array}{c}\text { Альвеолярная кость, } \\
\text { ммоль/кг }\end{array}$ & $0,88 \pm 0,07$ & $\begin{array}{l}0,40 \pm 0,06 \\
\mathrm{p}<0,001\end{array}$ & $\begin{array}{c}0,83 \pm 0,09 \\
\mathrm{p}>0,1 \\
\mathrm{p}_{1}<0,001\end{array}$ \\
\hline
\end{tabular}

Пр име ч ан ие : $\mathrm{p}$ - достоверность отличий от показателей в интактной группе; $\mathrm{p}_{1}$ - достоверность отличий от показателей в группе «МКГ».

Наряду с увеличением интенсивности перекисных процессов в тканях животных при МКГ отмечено достоверное снижение активности антиоксидантного фермента каталазы. В сыворотке крови этот показатель снизился на 43,8 \%, в печени - на $32,3 \%$, в СОПР - на $31,2 \%$ и в костной ткани альвеолярного отростка - на 19,9 \%. Введение ЛПК эффективно предотвращало падение активности каталазы. Активность этого фермента во всех исследуемых тканях крыс 3-ей группы соответствовала уровню здоровых животных (табл. 1).

Нарушения антиоксидантной защиты с одновременной интенсификацией ПОЛ демонстрирует антиоксидантно-прооксидантный индекс (АПИ). Так, у крыс 2-ой группы этот индекс сни- 
зился в сыворотке крови в 5,1 раза, в печени - в 2,6 раза, в СОПР - в 2,3 раза и в альвеолярной кости - в 2,2 раза. Проведение лечебнопрофилактических мероприятий способствовало достоверному увеличению АПИ во всех исследуемых тканях $\left(\mathrm{p}_{1}<0,001\right)$, но при этом только в ткани альвеолярной кости этот индекс был на уровне нормальных значений ( $\mathrm{p}>0,05)$.

Анализ результатов проведенного исследования показал, что кальций- дефицитная модель кариеса и гингивита приводит к снижению антиоксидантной защиты на фоне активации ПОЛ в организме животных. Использованные препараты предотвращют отдельные нарушения в системе АОС-ПОЛ сыворотки крови, печени, СОПР и костной ткани крыс, индуцированные алиментарным дефицитом кальция.

Интенсификация перекисных процессов в организме крыс на фоне МКГ, вероятнее всего, связана с ослаблением антиоксидантной системы не только на стадии инактивации перекисей (снижение активности каталазы), но также и ферментов обмена - глутатион-перокисдазы (ГПО) и глутатион- редуктазы (ГР) (табл. 2).

Таблица 2

\section{Влияние лечебно-профилактического комплекса на состояние ферментативной глутатионовой системы у крыс на фоне кальций-дефицитной модели, $\mathrm{M} \pm \mathbf{m}$}

\begin{tabular}{|c|c|c|c|}
\hline Ткани & Интактная группа & Модель кариеса и гингивита & МКГ + комплекс \\
\hline \multicolumn{4}{|c|}{ Активность глутатионпероксидазы } \\
\hline Сыворотка крови, ммоль/кг & $19,0 \pm 2,4$ & $\begin{array}{l}7,5 \pm 0,9 \\
\mathrm{p}<0,001\end{array}$ & $\begin{array}{c}12,6 \pm 1,1 \\
\mathrm{p}<0,05 \\
\mathrm{p}_{1}>0,001\end{array}$ \\
\hline Печень, ммоль/кг & $23,0 \pm 3,62$ & $\begin{array}{c}4,89 \pm 0,65 \\
\mathrm{p}<0,001\end{array}$ & $\begin{array}{c}13,8 \pm 1,7 \\
\mathrm{p}<0,05 \\
\mathrm{p}_{1}<0,001\end{array}$ \\
\hline СОПР, ммоль/кг & $11,2 \pm 0,89$ & $\begin{array}{c}8,53 \pm 0,11 \\
\mathrm{p}<0,005\end{array}$ & $\begin{array}{c}9,84 \pm 0,09 \\
p>0,1 \\
p_{1}<0,001\end{array}$ \\
\hline $\begin{array}{c}\text { Альвеолярная кость, } \\
\text { ммоль/кг }\end{array}$ & $6,99 \pm 1,02$ & $\begin{array}{c}2,10 \pm 0,53 \\
\mathrm{p}<0,001\end{array}$ & $\begin{array}{c}5,63 \pm 0,72 \\
\mathrm{p}>0,1 \\
\mathrm{p}_{1}<0,001\end{array}$ \\
\hline \multicolumn{4}{|c|}{ Активность глутатионредуктазы } \\
\hline Сыворотка крови, ммоль/кг & $0,96 \pm 0,13$ & $\begin{array}{c}0,58 \pm 0,07 \\
\mathrm{p}<0,05\end{array}$ & $\begin{array}{c}0,85 \pm 0,09 \\
\mathrm{p}>0,1 \\
\mathrm{p}_{1}<0,05\end{array}$ \\
\hline Печень, ммоль/кг & $0,12 \pm 0,02$ & $\begin{array}{c}0,07 \pm 0,01 \\
\mathrm{p}<0,05\end{array}$ & $\begin{array}{c}0,09 \pm 0,02 \\
\mathrm{p}>0,1 \\
\mathrm{p}_{1}>0,1\end{array}$ \\
\hline СОПР, ммоль/кг & $0,08 \pm 0,01$ & $\begin{array}{c}0,06 \pm 0,01 \\
\mathrm{p}<0,01\end{array}$ & $\begin{array}{c}0,10 \pm 0,01 \\
\mathrm{p}>0,1 \\
\mathrm{p}_{1}<0,01\end{array}$ \\
\hline $\begin{array}{c}\text { Альвеолярная кость, } \\
\text { ммоль/кг }\end{array}$ & $0,15 \pm 0,02$ & $\begin{array}{c}0,04 \pm 0,003 \\
\mathrm{p}<0,001\end{array}$ & $\begin{array}{c}0,13 \pm 0,02 \\
\mathrm{p}>0,1 \\
\mathrm{p}_{1}<0,001\end{array}$ \\
\hline
\end{tabular}

Пр име чан ие : p - достоверность отличий от показателей в интактной группе; $\mathrm{p}_{1}$ - достоверность отличий от показателей в группе «МКГ».

Под воздействием пелентана и ЭДТА активность ГПО снизилась в сыворотке крови в 2,5 раза $(\mathrm{p}<0,001)$, в печени - в 4,7 раза $(\mathrm{p}<0,001)$, в СОПР - в 1,3 раза $(\mathrm{p}<0,005)$, в кости альвеолярного отростка - в 3,3 раза (р $<0,001$; табл. 2).

Активность ГР, фермента, регенерирующего дисульфидные соединения, также снижалась на фоне моделирования МКГ во всех исследуемых тканях, за исключением СОПР. В сыворотке крыс 2-ой группы отмечено уменьшение активности ГП на $39,6 \%$, в печени - на $41,7 \%$, и в наибольшей степени в костной ткани альвеолярного отро- стка - на 73,3 \%. Назначение профилактических препаратов крысам 3-ей группы эффективно предупреждало снижение активности глутатионовой антиоксидантной защиты (табл. 2).

Моделирование сочетанной патологии кариеса и гингивита вызывает накопление сульфгидрильных и дисульфидных глутатионовых соединений во всех исследуемых тканях крыс (табл. 3). Такое увеличение объясняется снижением при моделировании патологии активности ГПО и ГР. 

Влияние лечебно-профилактического комплекса на состояние неферментативной
глутатионовой системы у крыс на фоне кальций-дефицитной модели, $\mathbf{M} \pm \mathbf{m}$

\begin{tabular}{|c|c|c|c|}
\hline Ткани & Интактная группа & Модель кариеса и гингивита & МКГ + комплекс \\
\hline \multicolumn{4}{|c|}{ Содержание SH-групп } \\
\hline Сыворотка крови, ммоль/кг & $12,5 \pm 1,6$ & $\begin{array}{c}20,9 \pm 3,2 \\
\mathrm{p}>0,01\end{array}$ & $\begin{array}{c}10,8 \pm 0,9 \\
\mathrm{p}>0,1 \\
\mathrm{p}_{1}<0,009\end{array}$ \\
\hline Печень, ммоль/кг & $8,37 \pm 3,62$ & $\begin{array}{c}16,30 \pm 0,53 \\
\mathrm{p}<0,001\end{array}$ & $\begin{array}{c}10,4 \pm 0,93 \\
\mathrm{p}>0,1 \\
\mathrm{p}_{1}<0,001\end{array}$ \\
\hline СОПР, ммоль/кг & $4,12 \pm 0,32$ & $\begin{array}{c}6,25 \pm 0,53 \\
\mathrm{p}<0,004\end{array}$ & $\begin{array}{c}5,22 \pm 0,48 \\
\mathrm{p}>0,05 \\
\mathrm{p}_{1}>0,01\end{array}$ \\
\hline Альвеолярная кость, ммоль/кг & $2,54 \pm 0,23$ & $\begin{array}{c}3,51 \pm 0,23 \\
\mathrm{p}<0,009\end{array}$ & $\begin{array}{c}2,94 \pm 0,35 \\
p>0,1 \\
p_{1}>0,1\end{array}$ \\
\hline \multicolumn{4}{|c|}{ Содержание SS-групп } \\
\hline Сыворотка крови, ммоль/кг & $2,6 \pm 0,3$ & $\begin{array}{l}4,1 \pm 0,06 \\
p<0,001\end{array}$ & $\begin{array}{c}2,8 \pm 0,3 \\
\mathrm{p}>0,1 \\
\mathrm{p}_{1}<0,001\end{array}$ \\
\hline Печень, ммоль/кг & $3,07 \pm 0,45$ & $\begin{array}{c}5,82 \pm 0,53 \\
\mathrm{p}<0,05\end{array}$ & $\begin{array}{c}4,39 \pm 0,52 \\
\mathrm{p}<0,1 \\
\mathrm{p}_{1}>0,05\end{array}$ \\
\hline СОПР, ммоль/кг & $4,62 \pm 0,31$ & $\begin{array}{c}5,04 \pm 0,71 \\
\mathrm{p}>0,01\end{array}$ & $\begin{array}{c}5,58 \pm 0,86 \\
p>0,1 \\
p_{1}>0,1\end{array}$ \\
\hline Альвеолярная кость, ммоль/кг & $2,54 \pm 0,23$ & $\begin{array}{c}3,45 \pm 0,21 \\
\mathrm{p}<0,009\end{array}$ & $\begin{array}{c}3,09 \pm 0,25 \\
\mathrm{p}>0,1 \\
\mathrm{p}_{1}>0,1\end{array}$ \\
\hline
\end{tabular}

Пр име ч ан ие : $\mathrm{p}$ - достоверность отличий от показателей в интактной группе; $\mathrm{p}_{1}-$ достоверность отличий от показателей в группе «МКГ».

Восстановление активности глутатионовой антиоксидантной защиты при применении профилактического комплекса способствовало и нормализации уровня сульфгидрильных и дисульфидных глутатионовых соединений (табл. $3)$.

Bbводы. Проведенное экспериментальное исследование показало, что регулярное воздействие на организм крыс кальций-дефицитной модели кариеса и гингивита приводит к нарушениям в системе АОС-ПОЛ. Об этом свидетельствуют результаты исследования биохимических маркеров сыворотки крови, печени, слизистой оболочки полости рта и ткани альвеолярной кости крыс. Проведенне лечебно-профилактических мероприятий оказало выраженный лечебнопрофилактический эффект - стимуляцию антиоксидантной защиты в организме и тканях полости рта. Вследствие этого у экспериментальных животных, находившихся длительное время в условиях алиментарного дефицита кальция нормализовалась функциональные показатели сыворотки крови, печени, активности антиоксидантных ферментов, а также эффективно замед- лялись деструктивные процессы в костной ткани альвеолярного отростка.

\section{Список литературы}

1. Нефедова Е. С. Особенности влияния различных уровней антропогенного загрязнения промышленного города на стоматологический статус детей: автореф. дис. на соискание учен. степени канд. мед. наук: 14.02.01 / Нефедова Е. С. - Оренбургская государственная медицинская академия. - Оренбург, 2013. - 24 с.

2. Якубова I. I. Поширеність карієсу постійних зубів у дітей із загальносоматичною патологією, які мешкають на радіоактивно забруднених територіях / I. I. Якубова, Р. М. Хомяк // Експериментальна та клінічна фізіологія і біохімія. - 2004. - № 2. - C. 130-136.

3. Юсупов 3. Я. О влиянии техногенных факторов производственной и окружающей среды на распространённость и структуру патологии зубочелюстной системы / 3. Я. Юсупов, А. Б. Бабаев, Г. Г. Ашуров // Вестник Авиценны. 2017. - №2. - С. 261-265.

4. Левицкий А. П. Сравнительная оценка трех методов определения активности фосфатаз слюны / А. П. Левицкий, А. И. Марченко, Т. Л. Рыбак // Лабораторное дело. 1973. -№ 10. - С. 624-625.

5. Горячковский А. М. Критическая биохимия в лабораторной диагностике: Справочное пособие / Горячковский А. М. - Изд. 3-е вып. и доп. Одеса: Екологія. 2005. - С. 402-403. 
6. А.С.922637 СССР. МКИ 01 33/48. Способ определения активности глутатион-пероксидазы в биологических тканях / В. Пахомова, Н. Козлянина, Г. Крюкова. - Опубл. 25.04.82, Бюл. №15. -2 c.

7. Путилина Е. Ф. Определение активности глутатион-редуктазы / Е. Путилина // Методы биохи-мическитй исследований. - М.: Ин. Лит. 1982. - С.181-183.

8. Веревкина И. В. Колориметрический метод определения SH-групп и SS-связей в белках при помощи 5,5'дитиобис(2-нитробензойной кисло-ты)ДТНБК / И. В. Веревкина, Л. Г. Точилкина, И. А. Попова // Современные методы в биохиии. - М.: Медицина. - 1977. - С. 223-231.

\section{REFERENCES}

1. Nefedova E. S. Osobennosti vlijanija razlichnyh urovnej antropogennogo zagrjaznenija promyshlennogo goroda na stomatologicheskij status detej [Features of the influence of different levels of anthropogenic pollution of an industrial city on the dental status of children]: Abstract of a candidate's thesis of medical sciences. Orenburgskaya gosudarstvennaya meditsinskaya akademiya. Orenburg; 2013:24.

2. Yakubova I. I. Prevalence of dental caries in children with somatic pathology living in radioactively contaminated territories. Eksperymental'na ta klinichna fiziologija i biohimija. 2004; 2 : 130-136.
3. Yusupov Z. Ya., Babaev A. B., Ashurov G. G. On the influence of technogenic factors of production and the environment on the prevalence and structure of the pathology of the dentofacial system. Vestnik Avicenny. 2017; 2: 261-265.

4. Levitsky A. P., Marchenko A. I., Rybak T. L. Comparative evaluation of three methods for determining the activity of salivary phosphatases. Laboratornoe delo. 1973; 1: 624-625.

5. Goryachkovsky A. M. Kriticheskaja biohimija v laboratornoj diagnostike: Spravochnoe posobie [Critical biochemistry in laboratory diagnostics: a reference guide] Odessa: Ekologija; 2005:402-403.

6. Pachomova V., Kozlyanina N., Krukova G. B. Sposob opredeleniya aktivnosti glutation-peroksidazy $v$ biologicheskikh tkanyakh. [Method for determination the activity of the glutathione peroxidase in biological tissues]. A. s. 922637 SSSR 3, MKI 01 33/48. Publ.: 25.04.82. Bul. №15.

7. Putilina E. F. Opredelenie aktivnosti glutationreduktazy [Determination of the activity of glutathione reductase]. Moscow: Innovacionnaja literatura. 1982:181-183.

8. Verevkina I. V. Kolorimetricheskij metod opredelenija SH-grupp i SS-svjazej v belkah pri pomoshhi 5,5'ditiobis (2-nitrobenzojnoj kislo-ty) [Colorimetric method for determining SH-groups and SS-bonds in proteins using 5,5'dithiobis (2-nitrobenzoic acid)] Sovremennye metody $v$ biohiii. Moscow.: Medicina. 1977:223-231. 